\title{
The Performance of Stock and the Indicators
}

\author{
Norazidah Shamsudin, Wan Mansor Wan Mahmood, and Fathiyah Ismail
}

\begin{abstract}
Performance of a company usually reflects its stock price. Companies with a good performance supposedly will have a good demand on its stock, hence boost the price and vice versa. However, there's manipulation game in the market. Rumors, speculation and short-selling are among the manipulation activities that affect the fluctuation of stock price. Fundamental analysis could provide an accurate result on companies' performance which not only base on the company's stock price. This research been conducted to study the relationship of historical performance of selected Islamic banks towards their stock performance and to identify the most significant independent variable. This research is a fundamental analysis, hence financial ratios been used as the main tool to produce data of dependent and independent variables. The research been conducted on licensed Islamic Banks in Malaysia as listed by Bank Negara Malaysia and focus on three independent variables of profitability, efficiency and liquidity and to see their relationship towards the dependent variable of the bank's stock performance. A set of quarterly data from year 2007 to 2012 been used in conducting ratio analysis. The result been further analyse using STATA 10.1 software. This research provides result on significant and relationship direction of profitability, efficiency and liquidity towards the banks stock performance. It also proves the most significant independent variable which has the strongest impact towards the stock performance.
\end{abstract}

Index Terms-Fundamental analysis, efficiency, liquidity, profitability, stock performance

\section{INTRODUCTION AND LITERATURE REVIEW}

Stock price is a reflection of a company's performance. Companies with a good performance supposedly will have a good demand on its stock, hence boost the price and vice versa. Reference [1] mentioned that the performance of a bank can be represent by performance of the banks' share prices, as they often are good indicators of how well the banks are doing. However, there's manipulation game in the market. Rumors, speculation and short-selling are among the manipulation activities that affect the fluctuation of stock price. Fundamental analysis could provide a precise result on companies' performance which not only base on the company's stock price trend. This research been conducted to study the relationship of historical performance of selected Islamic banks towards their stock performance and to identify the most significant independent variable. As mentioned in [2] the price-earnings ratio is a wonderful shorthand measure for the valuation of companies and markets.

Manuscript received June 14, 2013; revised August 14, 2013. This work was supported in part by the Universiti Teknologi MARA (Terengganu) Excellent Fund under Grant (238/2011).

The authors are with the Universiti Teknologi MARA, Terengganu, Malaysia (e-mail: noraz772@tganu.uitm.edu.my, dwanmans@tganu.uitm.edu.my, fathi260@tganu.uitm.edu.my).
This research is base on fundamental analysis, hence financial ratios been used as the main tool to produce data of dependent and independent variables. The research been conducted on licensed Islamic Banks in Malaysia as listed by Bank Negara Malaysia and focus on three independent variables of profitability, efficiency and liquidity and to see their relationship towards the dependent variable of the Islamic bank's stock performance.

Reference [3] used Price Earnings (PE) ratio as indicator to measure the performance of Bangladesh's stock market. In the recent news reported in The Daily Star, he recommends that the country's PE ratio should be reduced to below 20 as it had been increased tremendously achieved at ratio of 29 in January 2011. He further defined; the PE ratio of a stock is a measure of the price paid for a share relative to the annual net income or profit earned by the company per share. Referred to Bursa Malaysia's website, PE ratio been described as the measurement to make a performance comparison of a company with that of the industry, and from one period to another. The formula provided is current market price divided by earnings per stock.

Profitability is a measurement which reflects the performance of a company. Reference [4] mentioned profitability is the ultimate test of managements operating effectiveness and success of a company. Reference [5] stated that Return on Asset (ROA) is one of the best measurements of efficiency in order to assess the company's performance. ROA had been widely used as a measurement for profitability and it reflects the ability of management to generate income on a given amount of total assets [6]. Reference [7] agrees that ROA is one of popular profitability measures, which is a ratio between earnings after tax and total assets.

Reference [8] quote from Chien and Song, 2004 who had concluded that most previous studies concerning company performance evaluation focus merely on operational efficiency and operational effectiveness which might directly influence the survival of a company. Reference [9] explained efficiency as the non-wasteful use of resources. As in [10] further detailed on the measurement of efficiency that could be retrieved from Balance Sheet and Income Statement of a company which could be done by comparing sales and investment in various assets. Comparing company's sales and total assets is the formula for Total Assets Turnover (TATO).

Relating to liquidity performance, as in [11] explained their findings on their study of Hong Kong stock market that liquidity is an important factor for pricing returns in Hong Kong after taking well-documented asset pricing factors into consideration. They also compared alternative factor models and found that the liquidity four-factor model (market excess return, size, book-to-market ratio, and liquidity) is the best model to explain stock returns in the Hong Kong stock market, while the momentum factor is not found to be priced. 
Reference [12] stated that the measurement of liquidity should answer the question on how the company could pay its short-term debts and Loan to Deposit (LTD @ CR) is the measurement in picturing liquidity as for finance company. As for finance company, loan is their current asset and deposit is their current liability.

\section{Problem Statement}

Investors would buy share which could fulfill their investment objective on earning capital gain which concerns more on sustainability and growth. However, there's manipulation game in the market. Rumors, speculation and short-selling are among the manipulation activities that affect the fluctuation of stock price. This will affect the technical analyst prediction and stock selection in the market to become inaccurate. Today's markets are much more chaotic and choppy compared to previous decades and this is because of hedge funds and computerized ultra-short term trading activity which the result is more false signals and ill-formed patterns from technical analysis techniques [13]. Fundamental analysis could provide an accurate result on companies' performance which not only base on the company's stock price movement. As in [14], found that firms with low ratios of fundamentals to market values are known to have systematically lower future stock returns. Hence, this research should be conducted to provide answer on fundamental analysis performance. Fundamental analysis performance could provide better referencing for investors in selecting their investment portfolio.

\section{Methodology AND ANALYSIS}

\section{A. Method and Material}

There are two methods could be used to predict stock movement in upcoming period. The most used method is technical analysis which will look on the price movement trend and very volatile in sense of it will reflect to base of internal and major of external factors. Another method is fundamental analysis (ratio analysis) which is more stable because it based on historical of a firm and whereby all the internal and external factors influenced been adjusted accordingly for a certain period. In order to predict stock performance using fundamental analysis, the study focused on segments of ratio under ratio analysis that are profitability, efficiency and liquidity. The study determined which independent variable has the most significant influence towards the stock performance and which is the least.

A set of quarterly data from first quarter year 2007 to the fourth quarter of 2012 (24 quarter) been used in conducting ratio analysis. The raw data for financial ratio calculation been gathered on eight licensed Islamic Banks in Malaysia which make available complete financial quarterly report for the time frame needed. The result generated been further analyzed by regression analysis using STATA 10.1 software. As been mentioned above, the study focuses on three independent variables of profitability, efficiency and liquidity and to see their relationship towards the dependent variable of Islamic Bank's stock performance. Hence, the logarithm equation is written as in (1).

$$
1 \mathrm{nPE}_{i, t}=\alpha+\beta 1 \ln \left(\mathrm{ROA}_{i, t}\right)+\beta 2 \ln \left(\mathrm{TATO}_{i, t}\right)+\beta 3 \ln \left(\mathrm{CR}_{i, t}\right)+u_{i, t}
$$

Base on panel data analysis in [15], three models and two test could be used for analysis that are Pooled Ordinary Least Square Models (POLS), Random Effect Model (REM), Fixed Effect Model (FEM), Breusch and Pagan Langarian Multiplier Test and Hausman Fixed Test. Hence, for result generation, firstly the descriptive statistics has been generated in giving fundamental idea on characteristics of each variable. For measuring strength on relationship between the independent variables and dependent variable, F-test and T-test been conducted. Breusch and Pagan Lagangrian Multiplier test then been performed in order to specify the analysis of this research either choosing for Pooled Ordinary Least Square or Random Effect Model. Later, Hausman fixed test been run in determining the result of selecting Random Effect Model (REM) or Fixed Effect Model (FEM).

\section{B. Analysis}

The descriptive statistics on dependent and independent variables for this study as shown below:

\begin{tabular}{r|rrrr}
\multicolumn{5}{|c}{ TABLE I: DESCRIPTIVE STATISTIC } \\
stats & pe & roa & tato & cr \\
\hline mean & 1.085374 & .0052999 & .0189478 & 1.120939 \\
max & 18.42593 & .2283579 & .0819078 & 2.362087 \\
min & .0001439 & $1.76 e-06$ & .0020205 & .979799 \\
variance & 4.899071 & .0003626 & .0002377 & .0145507 \\
CV & 2.039282 & 3.593113 & .8136481 & .1076118 \\
sd & 2.213385 & .0190431 & .0154168 & .1206263 \\
\hline
\end{tabular}

Table I above demonstrates the descriptive statistics on dependent and independent variables. It summarizes the data in explaining the variation of the data's size and give fundamental idea on characteristics of each variable. Mean indicates the average of data's total values over its sample size. Besides mean, standard deviation also can be observed in this descriptive table. The highest mean is $\mathrm{CR}$ that is 1.120939 and the same indicator demonstrates the highest standard deviation among the independent variables with 0.1206263 . The lowest mean represents by ROA with very small number of 0.0052999 , however its coefficient of variation signify the highest value at 3.593113 as a result of its small mean's value. Coefficient of variation for each variable enlightens description on dispersion of the variable regardless of its number of unit.

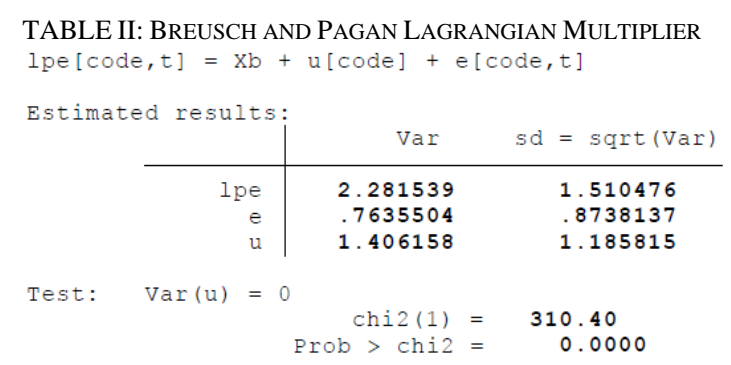

Breusch and Pagan Lagrangian Multiplier test been used to analyze the random effects. Through this test, Pooled 
Ordinary Least Square or Random Effect Model which accommodate the finest method will be chosen. Referring to the Breusch and Pagan Lagrangian Multiplier's result in Table II above, the value of prob > chi2 is 0.0000 which is less than 0.01 . So, null hypothesis will be rejected as the model is significant at $1 \%$ significance level. Hence, alternate hypothesis will be accepted and Random Effect Model will be selected for further study analysis.

TABLE III: HAUSMAN FIXED TEST

\begin{tabular}{|c|c|c|c|c|}
\hline & $\begin{array}{l}\text { (b) } \\
\text { fixed }\end{array}$ & $\begin{array}{c}\text { (B) } \\
.\end{array}$ & $\begin{array}{c}(b-B) \\
\text { Difference }\end{array}$ & $\begin{array}{c}\operatorname{sgrt}\left(\operatorname{diag}\left(V_{-} b-V_{-} B\right)\right) \\
\text { S.E. }\end{array}$ \\
\hline lroa & -.2066739 & -.2124722 & .0057984 & .0102921 \\
\hline ltato & -.6715908 & -.6760679 & .004477 & .0234164 \\
\hline lor & -.3155016 & -.4944996 & .178998 & .1976381 \\
\hline
\end{tabular}

$$
\begin{aligned}
\operatorname{chi2}(3) & = & (b-B)^{\prime}\left[\left(V_{b} b-V_{-} B\right)^{\wedge}(-1)\right](b-B) \\
& = & 0.91 \\
\text { Prob }>\operatorname{chi2} & = & 0.8224
\end{aligned}
$$

Hausman Fixed test been conducted in order to recognize the appropriateness of selecting Random Effect Model or Fixed Effect Model. As shown in Table III above, Prob $>$ chi $^{2}$ is at 0.8224 . Thus, Random Effect Model automatically been elected as the chi ${ }^{2}$ value is more than 0.05 . Null hypothesis has been accepted in this study where the Random Effect Model will be used because of the difference in coefficients not systematic. Hence, base on Hausman Fixed result, this study will stop at the random-effects GLS regression as it is more efficient than using the fixed-effects regression.

TABLE IV: RANDOM EFFECT GLS REGRESSION

\begin{tabular}{r|rrrrrr}
\hline lpe & Coef. & Std. Err. & $z$ & P $|z|$ & [958 Conf. Interval] \\
\hline lroa & -.2124722 & .081114 & -2.62 & 0.009 & -.3714528 & -.0534917 \\
ltato & -.6760679 & .173072 & -3.91 & 0.000 & -1.015283 & -.336853 \\
lcr & -.4944996 & 1.221623 & -0.40 & 0.686 & -2.888837 & 1.899838 \\
cons & -4.899477 & .7625796 & -6.42 & 0.000 & -6.394106 & -3.404848 \\
\hline sigma_u & 1.1858153 & & & & \\
sigma e & .87381374 & & & & \\
rho & .64808615 & (fraction of variance due to u_i) & \\
\hline
\end{tabular}

Table IV proved the significant level of the independent variables towards the dependent variable. Both significant independent variables that are TATO and ROA are inverse relationship with its dependent variable that is PE. It illustrate TATO has perfectly negative significant to PE with value of 0.000 and as for ROA, the significant level is at $5 \%$ that is at 0.009 .

From the result, the modified logarithm equation is written as in (2).

$$
\begin{aligned}
& 1 \operatorname{lnE}_{i, t}=4.899477-0.2124722 \ln \left(\mathrm{ROA}_{i, t}\right)-0.6760679\left(\mathrm{TATO}_{i, t}\right) \\
& -0.4944996 \operatorname{lnCR}_{i, t}+u_{i, t}
\end{aligned}
$$

Equation (2) exemplifies the level of influence of independent variables toward the dependent variable. It shows $1 \%$ increase in ROA will decrease PE by $0.2124722 \%$ ceteris paribus. Same case for the other two independent variables which $1 \%$ increases in TATO and CR will decrease PE by $0.6760679 \%$ and $0.4944996 \%$ respectively.

TABLE V: RANDOM EFFECT-TWO WAY ESTIMATION

\begin{tabular}{r|rrrrrr}
\hline lpe & Coef. & Std. Err. & $z$ & P $|z|$ & [95\% Conf. Interval] \\
\hline lroa & -.2307136 & .0854494 & -2.70 & 0.007 & -.3981914 & -.0632359 \\
ltato & -.6982544 & .182516 & -3.83 & 0.000 & -1.055979 & -.3405296 \\
lcr & -1.116479 & 1.295125 & -0.86 & 0.389 & -3.654877 & 1.421918 \\
year & -.0024248 & .0053223 & -0.46 & 0.649 & -.0128563 & .0080067 \\
_cons & 43.7028 & 106.8905 & 0.41 & 0.683 & -165.7986 & 253.2042 \\
\hline sigma u & .57160423 & & & & \\
sigma_e & .87711652 & & & & \\
rho & .29809497 & (fraction of variance due to u_i) & \\
\end{tabular}

The Random Effect-Two Way Estimation is conducted for the purpose to include the year (quarter) as additional independent variable to determine the time effect towards stock performance. Base on p-value of the z-test in Table V above, it shows year is not significant as the independent variable in this study. However, the former independent variables that are every proxy of profitability, efficiency and liquidity are still reflecting the same level of significant.

\section{DISCUSSION}

Base on descriptive analysis which shows the mean, maximum and minimum value, variance, standard deviation and coefficient of variations, it shows liquidity performance which represents by the current ratio provides the highest expected return as justified by mean and also it has the highest risk among the independent variables as justified by the standard deviation. The result constant with the general theory of risk and return relationship which suggest the highest risk contributor would reflect to the highest return. However, the coefficient of variations indicates the ROA which represents the profitability performance as the highest risk per unit of return. This is because ROA obtain very small value of mean and that creates the coefficient of variations to be high.

Random Effect Model been proceed since test conducted by Breusch and Pagan Lagrangian Multiplier confirm the rejection of null hypothesis for the reason that the model is significant at $1 \%$ significance level. Later, Hausman Fixed test been carried out in order to recognize the appropriateness of selecting Random Effect Model or Fixed Effect Model. The outcome of this test revealed that non-rejection of null hypothesis where the Random Effect Model been selected to further generate final result.

Random Effect GLS Regression discloses two independent variables have high significant levels that are TATO which contribute to perfect significant level and ROA is significant at 5\%. However, all independent variables have inverse direction movement towards the PE ratio. This proved that good stock performance for investor is when the $\mathrm{PE}$ is at low level. This is as result from the ratio formula of the indicators itself as in [3] explained the PE ratio is a measurement of the price paid for a share relative to the annual net income or profit earned by the company per share. Hence, the higher the earnings of the company, the lower the $\mathrm{PE}$ would be. It can be concluded where good performance of a company in investor's view is at the position of high profitability, better efficiency and low PE. Reference [3] 
further mentioned in the article that he used PE ratio as indicator to measure the performance of Bangladesh's stock market. It recommends that the country's PE ratio should be reduced to below 20 in order to improvise the investment market. A trend of negative correlation between market share and ROA in the series of data has been identified [16]. Reference [17] reveals that a firm's ranking in profitability (ROE or ROA) within its industry is negatively related to the sensitivity of its stock return to the industry-level return. The central prediction of study is that the stock returns of low-profitability firms are more sensitive compare to high-profitability firms.

As for efficiency, the result shows TATO has inverse relationship with PE. It means, good performance in TATO would reflect to good performance in PE. In other words, high TATO and low PE is a best set of indicator for company's performance. Reference [18] mentioned in their study that the increment on company's PE actually means they get slightly worse over long holding periods. Reference [19] mentioned TATO has negative correlation with stock return. Since TATO reflects efficiency in asset management to earn revenue from operating activities, thus a higher TATO is a benefit for the firm and can give positive effect on stock return. Same case applied to ROA where good performance in ROA would reflect to good performance in PE which means high ROA and low PE reflects the best performance for company.

The Random Effect GLS Regression in Table IV discloses LTD or CR is not significant where the $\mathrm{z}$-value is 0.686 . This constant with study conducted in [20] where they discovered that their study was contradictory to those previously conducted researches, suggesting that the current ratio has statistically no significant relationship with the stock price, which supports the study as well.

In addition, the Random Effect-Two Way Estimation been tested where year variable which represents the individual quarter been treated as additional independent variable in order to determine the effect of time indicator towards stock performance. Referring to Table $\mathrm{V}$, p-value for $\mathrm{z}$-test displays period is not significant as an individual independent variable towards performance of stock. However, the former selected independent variables still reflect the same level of significant [21], [22].

\section{CONCLUSION AND RECOMMENDATION}

Performance of a company is important to the origin company, its parent company, shareholders as well as potential shareholders. The performance of a company could help them to improve their financial management specifically and overall management strategy generally. Companies with a good performance supposedly will have a good demand on its stock, hence boost the price and vice versa. However, the manipulation game in the market which involved rumors, speculation and short-selling affect the fluctuations of stock price trend. Fundamental analysis could provide a precise result on companies' internal performance and the reflection towards their stock price. Reference [17] stated that high corporate performance grasps the attention of the investors in capital market and it reduces the risk level. Hence, it is suggested that the investor should refer to financial ratio performance as guidance for stock selection decision.

Base on the result of this study, as for conclusion, better performance of independent variables reflect to better performance of stock which the higher the TATO and ROA, the lower the PE would be. The results answer the key question on relationship between the independent and dependent variables which show inverse relationship of all independent variables towards the PE of a company and TATO appear to be as the most significant variable. In investment decision on Islamic Bank, the good performance of TATO and ROA could be used as a justification for stock selection. This could be generalized for investment decision on other companies from other industries. The outcomes of this study constant with a study done earlier which found strongly significant and positive effect of profitability toward company's overall efficiency and performance, as in [18].

With proven analysis, hopefully the outcome of this study could help the investors, remisiers or dealers to do stock performance prediction specifically on Islamic Banks and generally to finance industry's company base on company's financial performance. As for future researcher, it is suggested for them to include additional variables as representative for each ratio segment to test on the continuous of the outcome. It is also recommended to include extra frequent period which is if possible monthly instead of quarterly as been conducted in this study.

\section{ACKNOWLEDGMENT}

We are indebted to the Universiti Teknologi MARA (Terengganu) especially Research Management Institute who manage to grant the fund in conducting the research. We extend thanks to the colleagues and friends especially Miss Farazida Mohd Akit who has served as our Research Assistant outstandingly. Greatest gratitude and credits to everybody involved directly and indirectly in the accomplishment of this research.

\section{REFERENCES}

[1] E. Sekirin. (2010). How to evaluate performance of banks. [Online] Available:

http://www.ehow.com/how_6722963_evaluate-performance-banks.ht $\mathrm{ml}$

[2] J. Keefe. (2011). Price-earnings ratios: Would, coulds and shoulds for 2011. [Online] Available: http://moneywatch.bnet.com/economic-news

[3] M. F. Rahman. (2011). Reform the regulator. [Online] Available: http://www.thedailystar.net

[4] M. Safiullah, "Superiority of conventional banks \& Islamic banks of Bangladesh: A comparative study," International Journal of Economics and Finance, vol. 2, no. 3, pp. 199-207, 2010.

[5] D. Byard and F. Cebenoyan, "Alternative evidence on financial analysts' use of financial statement information," Review of Accounting and Finance, vol. 6, no. 4, pp. 442-459, 2007.

[6] G. W. Gallinger and P. B. Healy, Liquidity Analysis and Management, $2^{\text {nd }}$ ed. Addison Wesley Publishing Comp., 1991.

[7] S. J. Joo, D. Nixon, and P. A. Stoeberl, "Benchmarking with data envelopment analysis: A return on asset perspective," Benchmarking: An International Journal, vol. 18, no. 4, pp. 529-542, 2011.

[8] M. Tarawneh, "A comparison of financial performance in the banking sector: Some evidence from Omani commercial banks," International Research Journal of Finance and Economics, vol. 3, pp. 101-112, 2006.

[9] C. J. Woelfel, Encyclopedia of Banking and Finance, 10th ed. vol. 1, Publisher S. Chand and Company Ltd, 1994.

[10] G. Murray, "The concept of information, intractable uncertainty, and the current state of the efficient markets," Journal of Post Keynesian Economic, vol. 16, no. 3, pp. 325-349, 1994. 
[11] K. S. K. Lam and L. H. K. Tam, "Liquidity and assets pricing: Evidence from the Hong Kong stock market," Journal of Banking \& Finance, vol. 35, no. 9, pp. 1-14, 2011.

[12] T. Jeremy, "Liquidity-preference as a behavior towards risks," Review of Economics Studies, vol. 25, no. 1, pp. 69, 1958.

[13] P. Puri. (2010). The disadvantage of technical analysis for stock trading, published. [Online] Available: http://EzineArticles.com/3901363

[14] P. M. Dechow, A. P. Hutton, L. Meulbroek, and R. G. Sloan, "Short-sellers, fundamental analysis, and stock returns," Journal of Financial Economics, vol. 61, no. 1, pp. 77-106, 2001.

[15] A. R. Idris, F. F. A. H. Asari, N. A. A. Taufik, N. J. Salim, R. Mustaffa, and K. Jusoff, "Determinant of Islamic banking institutions' profitability in Malaysia," World Applied Science Journal, vol. 12, no. 12 , pp. 1-7, 2011.

[16] M. Magoro, "A study of a relationship between market share and profitability in listed South African retail companies," Masters Dissertation, University of Pretoria, MBA, 2009.

[17] X. C. Lin and Y. Zhang, "Bank ownership reform and bank performance in China," Journal of Banking \& Finance, vol. 33, no. 1, pp. 20-29, January 2009.

[18] K. Anderson and C. Brooks, "The long-term price-earnings ratio," Journal of Business Finance \& Accounting, vol. 33, no.7-8, pp. 1063-1086, 2006.

[19] K. Taani and M. H. H. Banykhaled, "The effect of financial ratios, firm size and cash flows from operating activities on earnings per share: (An applied study: On Jordanian industrial sector)," International Journal of Social Sciences and Humanity Studies, vol. 3, pp. 203-204, 2011.

[20] A. D. Limento and N. Djueriah. (2013). The determinant of the stock price in Indonesian, publicly listed transportation industry. Business and Information 2013. [Online]. pp. 790-792. Available: http://www.ibac-conference.org/BAI2013/Papers/3

[21] A. Siddiqui, "Financial contracts, risk and performance of Islamic banking," Managerial Finance, vol. 34, no. 10, pp. 680-694, 2008.

[22] R. Peavler. (2011). Use profitability ratios in financial ratio analysis: Determining profitability is important to company investors. [Online]. Available: http://www.bizfinance.about.com

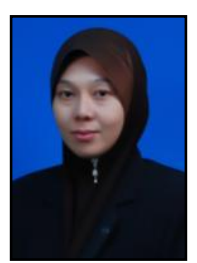

Norazidah Shamsudin graduated from International Islamic University Malaysia (IIUM) in MBA (Islamic banking and Finance) in the year 2010. Her former education is in BBA (Hons.) Islamic Banking in 2004 and Diploma in Banking in 2002 both from University Teknologi MARA, Malaysia. She currently serves as a lecturer at the Universiti Teknologi MARA, Terengganu, Malaysia. Prior from that, she worked as a marketing and processing executive at Mayfin Centre Dataran Maybank, Kuala Lumpur, Malaysia. As at to date, she has various writings and publications of book, chapter in books, journal article, proceeding paper, technical paper and general publication. Her interest area is in Islamic Banking and Finance. Ms. Shamsudin currently holds a position of vice chairman of diploma in Banking Curriculum Coordinating Committee for the whole Universiti Teknologi MARA system and also sharing her knowledge by providing weekend lecture on Islamic Finance course at Terengganu Advanced Technical Institute University College (TATIUC).

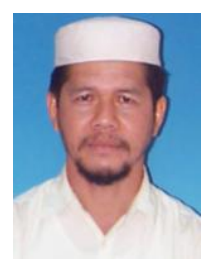

Wan Mansor Wan Mahmood is a professor in the Department of Finance, Faculty of Business and Management Universiti Teknologi MARA Terengganu. $\mathrm{He}$ received his bachelor degree and master degree in the US. In 1999, he obtained his Ph.D. from the Bangor University, Wales, UK. His specialization is in the area of financial economics, modeling time-series and futures market. Over the last several years, he has presented more than thirty papers in international conferences around the world, which include Australia, Italy, Japan, China, India, Turkey, Thailand, Tunisia, Vietnam and Indonesia. In addition, he has published many articles in refereed journal such as Economic Letter, International Research Journal of Finance and Economics, Pacific Rim Property Research Journal Euro-Mediterranean Economics and Finance Review and many more. Mahmood also reviewed papers for international refereed journals which include Japan and the World Economy, Sains Malaysiana, International Islamic University Malaysia Journal of Economics and Management (JEM), Asian Academy of Management Journal of Accounting and Finance (JAF), Asian Journal of Business and Accounting (AJBA), World Applied Science Journal (WASJ), International Journal of Economic Research (IJER) and many more. Currently, he is the chief editor for Terengganu International Finance and Economic Journal (TiFEJ) sits on the editorial board for the Capital Market Review journal. He is a life member of Malaysian Finance Association and an ordinary member of Asian Finance Association. He is also the recipient of university excellent award for three times - 1993, 2002 and 2006.

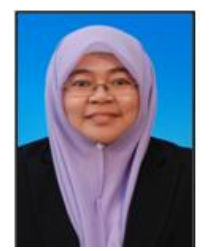

Fathiyah Ismail is a lecturer of Faculty of Business Management, UiTM Terengganu. She was born in 1977 in Alor Star, Kedah, Malaysia. In her current position, Fathiyah Ismail teaches courses in finance and Islamic banking. She received her bachelor of business administration (Hons.) finance in 2000 from Universiti Teknologi MARA Shah Alam Malaysia and pursued her MBA in 2001 from the same university. She has been with UiTM Terengganu for eleven years. Her primary areas of interest include investment analysis, Malaysian derivatives portfolio management and applications and Islamic takaful/insurance. Fathiyah Ismail has presented 4 research papers in a few international conferences and published her research papers in a few journals such as Terengganu International Finance and Economics Journal, TIFEJ and she now is actively writing articles for local buletins in her universiti and conducting researches for confereces. One of her papers has been rewarded Best Paper Award in International Management Conference, 2011. UiTM is Ms. Ismail's first career till date and she is actively involving herself in research and writing after four years holding a position as a faculty coordinator since year 2009 until 2013. 